\title{
Ewa Konefat
}

Uniwersytet Gdański

ekonefal@ug.edu.pl

\section{Dydaktyka thumaczenia ustnego: $\mathrm{z}$ historii rosyjskiej refleksji badawczej}

Efektem osiemdziesięcioletniej rosyjskiej ${ }^{1}$ refleksji naukowej nad fenomenem przekładu jest ponad dwa tysiące dysertacji ${ }^{2}$ przedłożonych w celu uzyskania stopnia naukowego kandydata ${ }^{3}$ i doktora ${ }^{4}$. Rozprawy te prezentują wyniki wieloletnich poszukiwań badawczych prowadzonych w ramach różnorodnych - odległych od siebie - dziedzin nauki, od nauk matematycznych po nauki o sztuce. Sporą część tego wciąż słabo znanego - pomimo pewnych wysiłków przedstawicieli polskiej i światowej translatologii - dorobku stanowią rozprawy koncentrujące się wokół zagadnień związanych z dydaktyką odmiany translacji powszechnie uważanej za najtrudniejszą - tłumaczenia ustnego ${ }^{5}$. Z przykrością należy odnotować, że wiedza na temat koncepcji przedstawicieli tzw. szkoły

1 Używając określenia „rosyjski”, mam na uwadze język omawianych dokumentów.

2 Wszystkie wnioski oraz przytaczane dane liczbowe prezentuję na podstawie wykazu autoreferatów dysertacji kandydackich i doktorskich z zakresu badań nad przekładem powstałych na terenie ZSRR, Federacji Rosyjskiej oraz terenie postradzieckim za lata 1937-2015, zamieszczonego w monografii [Konefał, 2016].

3 Ros. кандидат, w polskiej nomenklaturze odpowiednik stopnia doktora (anglosaskiej - PhD).

4 Ros. доктор, w polskiej nomenklaturze odpowiednik stopnia doktora habilitowanego.

5 Próby przybliżenia osiągnięć radzieckiej szkoły thumaczenia ustnego (jednakże bez akcentu na jego dydaktykę) były podejmowane przez Małgorzatę Tryuk [2013: 61-64] oraz Annę Bednarczyk [2016: 86-87]. O historii tłumaczenia ustnego w Rosji zob. Routledge Encyclopedia of Interpreting Studies [Burlyay, Matyushin, Yermolovich, 2015: 362-365]; tamże hasło poświęcone Czernowowi [Salevsky, 2015: 47-48]. 
radzieckiej tłumaczenia ustnego ogranicza się do myśli postaci najbardziej reprezentatywnych - Gielija Czernowa, Anatolija Szyriajewa oraz Ruryka Minjara-Biełoruczewa [Burlyay, Matyushin, Yermolovich, 2015: 365], przy czym szerzej znana i najczęściej cytowana jest myśl tylko pierwszego z nich. Poruszane przez wyżej wymienionych autorów kwestie kształcenia tłumaczy ustnych są przywoływane marginalnie, podobnie jak propozycje pozostałych rosyjskojęzycznych badaczy związanych z omawianym zagadnieniem. W niniejszym artykule chciałabym istniejącą lukę wypełnić (w zakresie, na jaki pozwalają jego ramy), przybliżając dorobek radzieckiej i postradzieckiej translatologii związany z dydaktyką thumaczenia ustnego, udokumentowany w postaci autoreferatów rozpraw przedłożonych do obrony w latach 1937-2015.

\section{Badania nad dydaktyką tlumaczenia ustnego: kilka danych kwantytatywnych}

Proces tłumaczenia ustnego może być oglądany z perspektywy różnych dziedzin nauki, z wykorzystaniem właściwego im aparatu i dominujących paradygmatów. Zgromadzony na przestrzeni analizowanego okresu dorobek poświęcony tej kwestii powstał na gruncie trzech dziedzin: nauk pedagogicznych, nauk filologicznych (grupy specjalności językoznawczych) oraz nauk psychologicznych (zob. tabela 1).

Do najliczniejszych, co szczególnie nie dziwi, należą autoreferaty rozpraw powstałe w ramach nauk pedagogicznych, tj. prace stricte dydaktyczne, poświęcone opracowaniu metodyki nauczania określonej odmiany tłumaczenia ustnego lub całego cyklu kształcenia akademickiego tłumaczy. Na przestrzeni analizowanego okresu różnym aspektom dydaktyki tłumaczenia ustnego badanym $w$ ich ramach zostały poświęcone aż 34 autoreferaty dysertacji (kandydackich i doktorskich). O dużym zainteresowaniu badawczym omawianym zagadnieniem świadczy fakt, iż stanowią one $18,3 \%$ badań nad przekładem prowadzonych w ramach specjalności pedagogicznych. Rozpraw poświęconych tłumaczeniom ustnym powstałych $\mathrm{w}$ ramach specjalności językoznawczych jest już znacznie mniej (zob. tabela 1). Stanowią one przy tym nikły procent badań nad przekładem inicjowanych na gruncie językoznawstwa. Do najmniej licznych należą natomiast autoreferaty dysertacji przedłożonych 
w celu uzyskania stopnia naukowego w zakresie nauk psychologicznych (których, notabene, jest i tak niewiele).

Tabela 1. Zestawienie sumaryczne autoreferatów dysertacji $\mathrm{z}$ zakresu tłumaczenia ustnego przedłożonych $\mathrm{w}$ ramach poszczególnych dziedzin/grup specjalności w ujęciu chronologicznym (na tle - ujętej w nawias - ogólnej liczby autoreferatów w danej dziedzinie/grupie specjalności)

\begin{tabular}{|c|c|c|c|}
\hline \multirow{2}{*}{ Lata } & \multicolumn{3}{|c|}{ Dziedzina / grupa specjalności } \\
\cline { 2 - 4 } & $\begin{array}{c}\text { Jezzykoznaw- } \\
\text { stwo }\end{array}$ & $\begin{array}{c}\text { Nauki } \\
\text { pedagogiczne }\end{array}$ & $\begin{array}{c}\text { Nauki } \\
\text { psychologiczne }\end{array}$ \\
\hline $1930-1939$ & $-(2)$ & $-(-)$ & $-(-)$ \\
\hline $1940-1949$ & $-(2)$ & $-(-)$ & $-(-)$ \\
\hline $1950-1959$ & $-(30)$ & $1(9)$ & $-(-)$ \\
\hline $1960-1969$ & $-(63)$ & $-(1)$ & $-(-)$ \\
\hline $1970-1979$ & $4(127)$ & $1(5)$ & $1(3)$ \\
\hline $1980-1989$ & $3(154)$ & $5(13)$ & $-(2)$ \\
\hline $1990-1991$ & $1(178)$ & $6(19)$ & $1(1)$ \\
\hline $2000-2009$ & $3(589)$ & $12(84)$ & $-(1)$ \\
\hline $2010-2015$ & $-(227)$ & $9(55)$ & $-(1)$ \\
\hline Razem & $\mathbf{1 1 ( 1 3 7 2 )}$ & $\mathbf{3 4}(\mathbf{1 8 6})$ & $\mathbf{2}(\mathbf{8})$ \\
\hline
\end{tabular}

Źródło: opracowanie własne na podstawie: Konefał, 2016.

\section{Początki refleksji naukowej}

Badania nad nauczaniem ustnej odmiany tłumaczenia zostają zainicjowane na gruncie nauk pedagogicznych. Znamienne jest, że pojawiają się one dużo wcześniej niż prace, teoretyczne i eksperymentalne, poświęcone thumaczeniu ustnemu powstające w ramach specjalności językoznawczych czy nauk psychologicznych. Prekursorem badań z zakresu dydaktyki thumaczenia ustnego jest Ruryk K. Minjar-Biełoruczew. Jego 
pierwsza, pionierska pod wieloma względami, dysertacja zostaje przedłożona (w celu uzyskania stopnia kandydata nauk pedagogicznych) już w 1956 r. [Миньяр-Белоручев, 1956] ${ }^{6}$, tj. de facto w momencie konstytuowania się przekładoznawstwa jako samodzielnej dyscypliny naukowej i przed pojawieniem się pierwszych zachodnich naukowych opisów prawidłowości ustnej odmiany translacji, pochodzących z lat 60.-70. ubiegłego stulecia (w Polsce $-\mathrm{z}$ lat 80.) [Tryuk, 2006: 6] ${ }^{7}$. Badania Minjara-Biełoruczewa uzasadniają stwierdzenie, iż ,to właśnie potrzeby dydaktyczne, konieczność uporządkowania ścieżki szkolenia i wyraźniejszego nakreślenia jego celów, doprowadziły do sformułowania pierwszych koncepcji/teorii thumaczenia ustnego" [Pöchhacker, 2004, za: Ruszel, 2006: 99]. W rozprawie przedstawiono koncepcję programu nauczania tłumaczenia specjalistycznego ${ }^{8}$,,ze słuchu"9 - jak je określa autor dysertacji - w obrębie pary języków francuski - rosyjski, rosyjski - francuski na potrzeby kształcenia thumaczy wojskowych ${ }^{10}$. Autor proponuje rozbicie kursu nauczania thumaczenia ustnego na cztery etapy: od najprostszego do najbardziej złożonego, z których do każdego został

6 Trzy lata później ukazuje się monografia autora poświęcona dydaktyce tłumaczenia ustnego [Миньяр-Белоручев, 1959].

7 Tamże adresy bibliograficzne prac przeglądowych na temat historii badań nad thumaczeniem ustnym.

8 Ze względu na gatunek tłumaczonego tekstu wyodrębniono trzy zasadnicze rodzaje przekładu: specjalistyczny (naukowo-techniczny), literacki i społeczno-polityczny.

9 Autor różnicuje teksty przekładu ze względu na sposoby percepcji komunikatu wyjściowego oraz realizacji tłumaczenia na: wzrokowo-pisemny (przekład materiałów drukowanych i rękopisów), przekład pisemny ze słuchu (komunikatów radiowych lub tekstów dyktowanych), wzrokowo-ustny (tłumaczenie a vista) oraz będące przedmiotem rozprawy tłumaczenie ustne ze słuchu (jednokierunkowe, dwukierunkowe itd.) [Миньяр-Белоручев, 1956: 1].

10 Ten obszar tłumaczenia cieszył się w ZSRR, i cieszy nadal, dużym zainteresowaniem badawczym, zaś odpowiednie przygotowanie tłumaczy na potrzeby armii zawsze traktowane było priorytetowo. Szkoły wojskowe (instytuty, w okresie późniejszym przekształcone w uniwersytety) to nie tylko kuźnia wysokiej klasy tłumaczy, ale również środowisko pracy dydaktycznej i naukowo-badawczej wybitnych przekładoznawców. W kształcącym tłumaczy wojskowych moskiewskim Instytucie Wojskowym pracowali, oprócz R. Minjara-Biełoruczewa, m.in. L. Barchudarow, A. Szwejcer, W. Komissarow, Ja. Recker, L. Nielubin. 
opracowany odpowiedni system ćwiczeń. Podstawowym ćwiczeniem na pierwszym etapie kształcenia jest tłumaczenie słuchowo-pisemne polega ono na thumaczeniu pisemnym tekstu czytanego w powolnym tempie przez wykładowcę, na celu ma zaś wykształcenie umiejętności rozumienia tekstu w najprostszych warunkach. Na tym etapie wykorzystywane są również ćwiczenia np. wzrokowo-ustne z języka rosyjskiego na francuski z powtórzeniami oraz „czytanie tekstu francuskiego”. $\mathrm{Na}$ etapach drugim oraz trzecim kształtowana jest technika tłumaczenia $a$ vista $\mathrm{z}$ języka francuskiego na rosyjski oraz z rosyjskiego na francuski bez korzystania ze słowników. Na trzecim etapie wprowadzane są kolejno zestawy ćwiczeń na tłumaczenia pisemne nagrań komunikatów ustnych, ćwiczenia łączące tłumaczenia a vista z francuskiego i rosyjskiego z dwustronnym thumaczeniem ustnym oraz ćwiczenia na tłumaczenia symultaniczne krótkich fraz. Na czwartym, i ostatnim, etapie kontynuowane jest kształcenie umiejętności tłumaczenia symultanicznego oraz przekład w sytuacji ,przesłuchania jeńca”. Podstawą koncepcji stały się osobiste doświadczenia autora jako czynnego tłumacza i wykładowcy. $\mathrm{W}$ odróżnieniu od badań z zakresu dydaktyki thumaczenia prowadzonych w latach późniejszych, koncepcja nie była weryfikowana na drodze eksperymentu.

\section{Lata 70. XX w.}

Kolejna rozprawa, również autorstwa Minjara-Biełoruczewa, przedłożona w celu uzyskania stopnia doktora nauk pedagogicznych w Akademii Nauk Pedagogicznych ZSRR, pojawia się dopiero w latach 70. XX w. [Миньяр-Белоручев, 1970] ${ }^{11}$. W dysertacji autor prezentuje podstawy teoretyczne nauczania thumaczenia konsekutywnego. Stanowią one sporą wartość nie tylko dla dydaktyki tłumaczenia ustnego, wnosi także wiele nowego, jak na ówczesny stan badań, do teorii translacji ustnej (w odróżnieniu od większości pozostałych rozpraw z dziedziny nauk pedagogicznych koncentrujących się przede wszystkim wokół

11 Rok wcześniej ukazują się pozycje książkowe autora: monografia poświęcona tłumaczeniu konsekutywnemu, w której została przedstawiona metodyka nauczania wraz z opracowanym przez autora systemem ćwiczeń oraz systemem notacji [Миньяр-Белоручев, 1969b], podręcznik poświęcony notacji [МиньярБелоручев, 1969c] oraz thumaczeniu ustnemu [Миньяр-Белоручев, 1969а]. 
problemów metodycznych, bez aspiracji do odkryć dotyczących prawidłowości samego procesu translacji). W rozprawie opisano działania thumacza, głównie mechanizmy myślowe, towarzyszące tłumaczeniu oraz istotną kwestię magazynowania informacji w thumaczeniu konsekutywnym (m.in. zastosowania notacji).

Lata 70. w językoznawstwie radzieckim to okres intensywnego rozwoju psycholingwistyki. Rozkwit ten wyraźnie wpływa na dynamikę prowadzonych w jej duchu badań nad przekładem ustnym powstających na gruncie językoznawstwa. Do obrony zostają przedłożone trzy dysertacje poświęcone tłumaczeniu symultanicznemu: dwie (kandydacka i doktorska) Anatolija Szyriajewa [Ширяев, 1973, 1979a] oraz Jeleny Sładkowskiej [Сладковская, 1979]. Celem rozprawy kandydackiej Szyriajewa [Ширяев, 1973] było zbadanie istoty lingwistycznych i psycholingwistycznych mechanizmów synchronizacji odbioru komunikatu w języku wyjściowym (francuskim) i jego produkcji w języku docelowym (rosyjskim) oraz wyodrębnienie w wypowiedzi wyjściowej czynników, które wpływają na synchronizację tłumaczenia. Celem drugiej z dysertacji, doktorskiej, było określenie wyjściowej, teoretycznej koncepcji psycholingwistycznych badań nad thumaczeniem symultanicznym jako wyspecjalizowanym rodzajem działalności mownej oraz opracowanie na jej podstawie psycholingwistycznego modelu thumaczenia symultanicznego [Ширяев, 1979a: 5]. Integralną część rozprawy stanowi opracowana przez autora metodyka kształcenia tłumaczy symultanicznych. W 1979 r. ukazuje się także monografia autora dotycząca thumaczenia symultanicznego, poruszająca również kwestie jego dydaktyki [Ширяев, 1979b].

Dysertacja Jeleny Sładkowskiej, w odróżnieniu od pozostałych przywoływanych tu prac, wychodzi poza ramy badań psycholingwistycznych. Przedmiotem rozprawy jest analiza nominatywnego aspektu tekstu (rozumianego przez autorkę jako zbiór nominacji obiektów i zjawisk opisywanych w tekście) w thumaczeniu symultanicznym. Jego jądro semantyczne stanowi bazowy komponent tematyczny (BKT) reprezentujący obiekty powtarzające się w tekście. Podstawą do wyodrębnienia BKT jest zjawisko rekurencji (rekursji) semantycznej w tekście. Odpowiedniość pomiędzy BKT tekstu wyjściowego i docelowego stanowi obiektywne kryterium oceny ekwiwalencji w przekładzie ustnym. 
W 1976 r. w Instytucie Językoznawstwa Akademii Nauk ZSRR badania nad psycholingwistycznymi aspektami przekładu ustnego finalizuje również Wasilij Andrijanow [Андриянов, 1976]. W dysertacji zostaje poruszony problem werbalnych i niewerbalnych zachowań tłumacza, głównie w warunkach tłumaczenia konsekutywnego. W przedstawionym modelu działalności translatorskiej tłumacz pełni funkcję socjalną. Dużą wagę posiadają relacje pomiędzy uczestnikami komunikacji, zaś ich status socjalny oraz wyobrażenia tłumacza o pełnionej funkcji determinują stosowane przez niego strategie wyboru środków werbalnych.

Wszystkie z przywołanych wyżej prac nie pozostają bez wpływu na dydaktykę thumaczenia, wymiar aplikatywny prowadzonych badań jest wyraźnie akcentowany przez ich autorów.

W omawianej dekadzie w Leningradzkim Państwowym Instytucie Pedagogicznym im. I.A. Hercena do obrony zostaje przedłożona również jedna dysertacja prezentująca wyniki badań nad tłumaczeniem ustnym prowadzonych na gruncie psychologii [Бенедиктов, 1972], skupiona wokół ogólnych i temporalnych aspektów tłumaczenia ustnego oraz posługiwania się językami obcymi (kwestia wielojęzyczności).

\section{Lata 80. XX w.}

Ożywienie badań nad przekładem ustnym prowadzonych w ramach nauk pedagogicznych następuje dopiero w latach 80 . Metodyka nauczania tłumaczenia ustnego posuwa się o krok naprzód. W dydaktyce zaczynają być wykorzystywane nowe technologie informacyjne, a wraz z nimi pojawiają się prace eksperymentalne związane z możliwościami usprawnienia procesu dydaktycznego, jakie owe technologie stwarzają. W 1981 r. powstaje autoreferat dysertacji Michaiła Miszyna [Мишин, 1981], w której została przedstawiona metodyka nauczania przekładu konsekutywnego (para angielski - rosyjski, początkowy etap kształcenia) z wykorzystaniem telewizji dydaktycznej w obwodzie zamkniętym (ros. учебная замкнутая цветная телевизионная система). Centrum telewizyjne moskiewskiego Instytutu Wojskowego, w którym autor przeprowadził eksperyment dydaktyczny, składało się z trzech bloków: sali studyjnej, kinowej i nagraniowej.

Z wykorzystaniem nowych technologii informacyjnych (nagrań dźwiękowych, filmów i diafilmów) związany jest również kolejny 
autoreferat z tego okresu, dysertacji przedłożonej przez Marinę Bukariewą [Букарева, 1986]. W rozprawie została przedstawiona metodyka organizacji prac laboratoryjnych w procesie kształcenia umiejętności rozumienia ze słuchu i mowy, jej efektem są zalecenia dla wykładowców oraz instrukcje dla studentów dotyczące samodzielnej pracy laboratoryjnej nad tłumaczeniem ustnym. Kwestia rozwijania sprawności rozumienia ze słuchu (ros. аудирование) - już bez akcentu na wykorzystanie nowych technologii - pojawia się również w dysertacjach Farita Idrisowa [Идрисов, 1987] oraz Natalii Gawrilenko [Гавриленко, 1989].

Ostatni z autoreferatów dysertacji powstałych w omawianym okresie [Григорьева, 1988] dotyczy zagadnień konsekutywnego thumaczenia bilateralnego (w obrębie pary angielski - rosyjski / rosyjski - angielski). Celem przeprowadzonych przez autorkę badań eksperymentalnych było określenie statusu tłumaczenia dwustronnego oraz stworzenie psychologicznego modelu takiego thumaczenia.

Lata 80. przynoszą także trzy autoreferaty rozpraw poświęconych tłumaczeniu ustnemu powstałe $\mathrm{w}$ ramach specjalności językoznawczych. W 1980 r. zostają zaprezentowane efekty badań teoretycznoeksperymentalnych prowadzonych przez Gelija Czernowa [Чернов, 1980] dotyczące psycholingwistycznych podstaw thumaczenia symultanicznego z języka obcego na język rodzimy ${ }^{12}$. Autor bada te właściwości tłumaczenia symultanicznego, które zapewniają zachowanie inwariantu semantycznego w tłumaczeniu oraz mechanizmów, które umożliwiają jednoczesną recepcję komunikatu wyjściowego i jego reprodukcję w języku docelowym. W rozprawie zostają poruszone istotne dla tego rodzaju thumaczenia kwestie, m.in. manifestującej się na różnych poziomach komunikatu redundancji semantycznej (obiektywnej i subiektywnej), roli szeregu implikacji encyklopedyczno-leksykalnych, sytuacyjnodeiktycznych oraz pragmatycznych wpływających na redundancję komunikatu źródłowego. Przedstawione w rozprawie koncepcje teoretyczne legły u podstaw opracowanej przez Czernowa (we współautorstwie)

12 Dwa lata po wydaniu monografii Теория и практика синхронного перевода, z rozdziałem poświęconym nauczaniu przekładu symultanicznego [Чернов, 1978: 162-193] i osiem lat przed klasyczną już pozycją Основы синхронного перевода [Чернов, 1987], która doczekała się angielskiego wydania [Chernov, 2004]. 
metodyki kształcenia tłumaczy symultanicznych. Efektem prowadzonych badań jest także opatentowanie (również we współautorstwie) urządzenia do analizy sygnału mowy, wykorzystywanego w procesie kształcenia thumaczy symultanicznych.

Dwa pozostałe autoreferaty dysertacji przedłożonych w omawianym dziesięcioleciu dotyczą mechanizmu przekształceń semantycznych $\mathrm{w}$ thumaczeniu ustnym, oglądanym $\mathrm{z}$ perspektywy psycholingwistyki [Зеленов, 1987] ${ }^{13}$ oraz teorii tekstu i lingwistyki komunikacyjnej [Чачибая, 1989].

\section{Lata 90. XX w.}

W latach 90. obserwowany jest nieznaczny wzrost dynamiki badań nad przekładem ustnym prowadzonych $\mathrm{w}$ ramach nauk pedagogicznych. W okresie tym zarejestrowano pięć autoreferatów dysertacji kandydackich i jedną doktorską. W pierwszym z zarejestrowanych w tym dziesięcioleciu dokumentów, autoreferacie dysertacji doktorskiej ${ }^{14}$ Iriny Chalejewej [Халеева, 1990], powraca kwestia rozumienia ze słuchu w procesie kształcenia tłumaczy ustnych. Autorka przedstawia podstawy teorii nauczania rozumienia obcojęzycznej mowy na podstawie integracji wiedzy językowej i kognitywnej. Prezentowane badania powstały na styku metodyki nauczania języków obcych oraz takich dyscyplin, jak językoznawstwo kognitywne i komunikacyjne, psycholingwistyka, etnosocjopsychologia, filozofia języka.

$13 \mathrm{~W}$ rozprawie zostały przedstawione wnioski istotne $\mathrm{z}$ punktu widzenia procesu kształcenia przyszłych tłumaczy. Autor opracował szereg zaleceń dotyczących kolejności przedmiotów w cyklu nauczania tłumaczenia ustnego: 1) przekład konsekutywny bez notacji; 2) przekład frazowy; 3) przekład konsekutywny z notacją; 4) przekład wzrokowo-ustny ( $a$ vista) z wcześniejszym przygotowaniem i bez przygotowania. Równolegle z kształceniem umiejętności w zakresie wszystkich wyżej wymienionych rodzajów tłumaczenia ustnego zaproponowano ćwiczenia (w postaci zadań domowych) związane z operacjami charakterystycznymi dla tłumaczenia ustnego (wybór ekwiwalentów, przekład synomimiczny, transformacje itd.) wykonywane na materiale przekładu pisemnego. Niezmiernie istotne w kształceniu zawodowym tłumaczy jest - zdaniem autora - także rozwijanie wiedzy encyklopedycznej.

Dysertacja wydana w postaci monografii [Халеева, 1989]. 
Najwięcej wysiłków badawczych włożono w opracowanie metodyki nauczania thumaczenia a vista $\mathrm{w}$ obrębie par języków: angielski hiszpański [Бассуэ, 1991], francuski - rosyjski [Живова, 1998]. Model psycholingwistyczny tej odmiany thumaczenia ustnego został zaprezentowany także w powstałej na gruncie językoznawstwa rozprawie Galiny Żarkowej [Жаркова, 1990].

Cele pozostałych rozpraw powstałych w ramach nauk pedagogicznych w tym okresie związane są z opracowaniem metodyk: kształtowania kompetencji ustnej studentów zagranicznych - przyszłych tłumaczy wojskowych [Сафонова, 1991], kształtowania podstawowych nawyków i umiejętności niezbędnych w tłumaczeniu konferencji międzynarodowych na początkowym etapie nauczania przekładu ustnego (w obrębie par językowych: francuski - rosyjski, rosyjski - francuski) [Самойленко, 1998], nauczania przekładu ustnego w ramach kursu translatorycznego dla studentów uczelni językowych Mongolii [Готов, 1999].

W latach 90. zarejestrowano również jeden, istotny dla dydaktyki tłumaczenia ustnego, autoreferat dysertacji powstałej w ramach nauk psychologicznych [Алексеева, 1992]. Autorka rozprawy obiektem przeprowadzonych na drodze eksperymentu badań czyni proces doskonalenia umiejętności tłumaczenia ustnego przez studentów uczelni językowych, celem zaś opisanie dynamiki konsolidacji pamięci operacyjnej (krótkotrwałej) z pamięcią długotrwałą na poszczególnych etapach nauki tłumaczenia ustnego (konsekutywnego i symultanicznego).

\section{Wiek XXI}

Półtorej dekady obecnego stulecia przyniosło znaczny skok ilościowy w badaniach nad dydaktyką tłumaczenia ustnego prowadzonych w ramach nauk pedagogicznych ${ }^{15}$. W latach 2000-2015 łącznie zostało zarejestrowanych 21 autoreferatów dysertacji poświęconych różnym

15 Podobny wzrost obserwowany jest w przypadku oferty wydawniczej dotyczącej podręczników akademickich. W obecnym stuleciu zostało wydanych około 100 różnych pozycji wspierających dydaktykę praktycznie wszystkich odmian tłumaczenia ustnego. Są wśród nich zarówno kolejne wydania klasycznych podręczników R.K. Minjara-Biełoruczewa, G.W. Czernowa czy A.F. Szyriajewa, jak i nowe (niekoniecznie zaś nowatorskie) opracowania. 
aspektom dydaktyki translacji ustnej. Charakteryzuje je spory rozrzut tematyczny i metodologiczny. Poruszane zagadnienia pozostają w większości niezmienne, poszerza się natomiast optyka spojrzenia na problem dydaktyki nauczania thumaczenia ustnego oraz na rolę przyszłego tłumacza ustnego oraz jego kompetencje.

Do wciąż aktualnych problemów (należy się zastanowić, czy nie nadmiernie eksploatowanych) należy opracowanie metodyki nauczania tłumaczenia a vista pism handlowych: z języka niemieckiego [Касаткина, 2000] i chińskiego [Алексеева, 2006] oraz ogólne zagadnienia nauczania tłumaczenia ustnego na uczelniach specjalistycznych: wojskowych (technicznych [Чуксина, 2000] i medycznych [Цуциева, 2006]) i ekonomicznych [Белькова, 2009] oraz językowych [Арутюнян, 2013].

Tematem przewodnim ostatnich 15 lat jest wykorzystanie tradycyjnych i innowacyjnych technologii oraz materiałów audio i wideo w procesie nauczania tłumaczenia ustnego (głównie konsekutywnego). Z zagadnieniem tym związane są autoreferaty rozpraw Oksany Kniaziewej [Князева, 2006], Olgi Żelezniakowej [Железнякова, 2010], Jewgienii Tichonowej [Тихонова, 2014], Anny Puszkiny [Пушкина, 2015].

Sporo uwagi badawczej koncentruje się wokół zagadnień doskonalenia różnorodnych kompetencji i umiejętności niezbędnych w thumaczeniu ustnym, mających na celu opracowanie i eksperymentalną weryfikację metodyki: doskonalenia tempa mowy w thumaczeniu konsekutywnym [Корзун, 2008], rozwijania sprawności rozumienia ze słuchu [Руцкая, 2012], kształtowania kompetencji emotywno-empatycznych [Карпова, 2011] і perceptywno-komunikacyjnych [Ярошенко, 2007], doskonalenia plastyczności (odpowiedniego doboru środków leksykalno-frazeologicznych) wypowiedzi [Кондрашина, 2012], poszerzania systemu wiedzy pozajęzykowej [Швецова, 2012], wykorzystania gier symulacyjnych w rozwoju kompetencji tłumaczy ustnych [Панова, 2014].

Uwaga badaczy skierowana jest również na problem wykorzystania systemu notacji $\mathrm{w}$ procesie przygotowania zawodowego thumaczy ustnych. Kształtowaniu nawyków i umiejętności w tym zakresie została poświęcona rozprawa Jeleny Alikinej [Аликина, 2002]. Podobne zagadnienie porusza Igor Fadiejew, przedmiotem swej rozprawy czyniąc opracowanie specjalnego systemu konspektywnego zapisu 
w thumaczeniu ustnym i pisemnym oraz metodyki jego nauczania podczas szkolenia tzw. thumaczy-referentów [Фадеев, 2001].

Odzwierciedleniem nowych tendencji w dydaktyce thumaczenia ustnego są przebrzmiewające idee nauczania interkulturowego (tzw. zwrot kulturowy obserwowany w wielu dziedzinach): spojrzenie na tłumaczenie ustne przez pryzmat komunikacji międzykulturowej [Бакало, 2003] oraz rozwoju kompetencji lingworealioznawczej [Емельянова, 2005].

Na tym tle wciąż zbyt mało - moim zdaniem - uwagi poświęca się dydaktyce nauczania najtrudniejszej z odmian ustnej translacji - tłumaczeniu symultanicznemu ${ }^{16}$. Kwestia ta pojawia się jedynie w rozprawie Julii Goman [Гоман, 2002].

Znamienny jest na tym tle spadek liczby badań nad przekładem ustnym prowadzonych $w$ ramach specjalności językoznawczych. $\mathrm{W}$ omawianym okresie zarejestrowano jedynie trzy autoreferaty w tym obszarze, dwa poświęcone strategiom translatorskim: w przekładzie symultanicznym [Илюхин, 2002] i konsekutywnym [Макаренко, 2002] oraz zjawisku kompresji w przekładzie symultanicznym [Гурин, 2009], przy czym wszystkie w pierwszej dekadzie obecnego stulecia. W latach 2010-2015 na gruncie językoznawstwa nie odnotowano ani jednego dokumentu związanego $\mathrm{z}$ tłumaczeniem ustnym. A jest to okres niezmiernie dynamiczny w najnowszej historii rosyjskich językoznawczo zorientowanych badań nad przekładem ${ }^{17}$.

\section{Podsumowanie}

Nie jestem w stanie zweryfikować słuszności tezy rosyjskich translatoryków Lwa Łatyszewa i Arkadija Siemionowa [Латышев, Семенов,

16 W ramach specjalności językoznawczych w tym czasie zostało przedłożonych 816 dysertacji (759 kandydackich i 57 doktorskich (!)), zob. Konefał, 2016: 59-60.

17 W ramach nauk pedagogicznych różnym aspektom dydaktyki przekładu oraz jego wykorzystaniu w procesie glottodydaktycznym zostało poświęconych 186 autoreferatów dysertacji, co stanowi 8,4\% wszystkich zarejestrowanych dokumentów (wykaz liczy 2202 pozycje). Pod względem ilościowym sytuują się one tuż po badaniach prowadzonych w ramach nauk filologicznych (językoznawstwa i literaturoznawstwa). 
2003: 162], iż kwestie dydaktyki przekładu należą do najmniej opracowanego obszaru pedagogiki. Autorzy w ubolewaniu nad zaniedbaniem badań nad dydaktyką tłumaczenia nie są odosobnieni [zob. np. Florczak, 2013: 53]. Zgromadzony i pokrótce przedstawiony materiał bibliograficzny pozwala mi jednakże stwierdzić, iż pod względem ilościowym, na tle ogółu podejmowanych badań nad przekładem, w tym także nad tłumaczeniem ustnym, dorobku rosyjskiej translatologii nie można uznać za marginalny ${ }^{18}$. Jedną z przyczyn jego nikłej znajomości na forum światowym jest $\mathrm{z}$ pewnością słabe umiędzynarodowienie prowadzonych badań, spowodowane wieloletnim izolacjonizmem rosyjskiej nauki zamkniętej za żelazną kurtyną. Gdybym miała prognozować dynamikę rosyjskich badań nad dydaktyką translacji ustnej w najbliższych dziesięcioleciach, przyznam, iż moim zdaniem posiadają one wciąż spory potencjał. Zwłaszcza te powstające na gruncie nauk pedagogicznych, gdyż punkt ciężkości w badaniach nad przekładem ustnym powoli przesuwa się z teorii ku jego dydaktyce. Jest to tendencja obserwowana nie tylko w Rosji. Nowe badania stymulują nie tylko wzmożony popyt na usługi translatorskie, ciągłe dążenie do doskonalenia metodyki nauczania (powstaje coraz więcej szkół kształcących tłumaczy, a wraz z nimi różnorodność modeli nauczania [роr. Новикова, 2013: 54]), w tym i nieodpartą chęć osiągnięcia poziomu europejskiego, ale również burzliwy rozwój nowych technologii, wykorzystywanych zarówno w praktyce translatorskiej, jaki i w procesie kształcenia przyszłych tłumaczy.

\section{Bibliografia}

Bednarczyk, A. (2016), Zmagania z przekładem w przestrzeni rosyjskojęzycznej. Teoria i praktyka ewolucji, Wydawnictwo Uniwersytetu Gdańskiego, Gdańsk.

Burlyay, S., Matyushin, I., Yermolovich, D. (2015), „Russia”, w: Pöchhacker, F. (ed.), Routledge Encyclopedia of Interpreting Studies, Routledge, London, s. 362-365.

18 W Polsce zob. np. Florczak, 2013; Chmiel, Janikowski, 2015. 
Chernov, G.V. (2004), Inference and anticipation in simultaneous interpreting. A probability-predication model, ed. R. Setton, A. Hild, John Benjamins Publishing Company, Amsterdam-Philadelphia.

Chmiel, A., Janikowski, P. (red.) (2015), Dydaktyka ttumaczenia ustnego, Stowarzyszenie Inicjatyw Wydawniczych, Katowice.

Florczak, J. (2013), Ttumaczenia symultaniczne i konsekutywne. Teoria i praktyka, Wydawnictwo C.H. Beck, Warszawa.

Konefał, E. (2016), Przektadoznawstwo rosyjskie, t. 1: Autoreferaty dysertacji (1937-2015), Wydawnictwo Uniwersytetu Gdańskiego, Gdańsk.

Pöchhacker, F. (2004), Introducing Interpreting Studies, Routledge, LondonNew York.

Ruszel, J. (2006), „Ocena kompetencji w kształceniu tłumaczy konferencyjnych; normy zawodowe a parametry dydaktyczne", w: Tryuk, M. (red.), Teoria i dydaktyka przekładu konferencyjnego. Z badań Instytutu Lingwistyki Stosowanej Uniwersytetu Warszawskiego, Wydawnictwo Takt, Warszawa, s. 99-117.

Salevsky, H. (2015), „Chernov”, w: Pöchhacker, F. (ed.), Routledge Encyclopedia of Interpreting Studies, Routledge, London, s. 47-48.

Tryuk, M. (2013), Przektad ustny konferencyjny, wyd. I - 1 dodruk, Wydawnictwo Naukowe PWN, Warszawa.

Tryuk, M. (red.) (2006), Teoria i dydaktyka przekładu konferencyjnego. Z badań Instytutu Lingwistyki Stosowanej Uniwersytetu Warszawskiego, Wydawnictwo Takt, Warszawa.

Латышев, Л.К., Семенов, А.Л. (2003), Перевод: теория, практика и методика преподования: учебное пособие, Академия, Москва.

Миньяр-Белоручев, Р.К. (1959), Методика обучения переводу на слух, Издво ИМО, Москва.

Миньяр-Белоручев, Р.К. (1969а), Курс устного перевода (французский язык), [б.и.], Москва.

Миньяр-Белоручев, Р.К. (1969b), Последовательный перевод. Теория и методы обучения, Воениздат, Москва.

Миньяр-Белоручев, Р.К. (1969c), Пособие по устному переводу (записи в последовательном переводе), Высшая школа, Москва.

Новикова, Э.Ю. (2013), „Устный перевод на стыке дидактических моделей и вызовов времени”, Вестник ЦМО МГУ, № 3. Методика, ss. 53-57. 
Халеева, И.И. (1989), Основы теории обучения пониманию иноязычной речи (подготовка переводчиков), Высшая школа, Москва.

Чернов, Г.В. (1978), Теория и практика синхронного перевода, Международные отношения, Москва.

Чернов, Г.В. (1987), Основы синхронного перевода: учебник для институтов и факультетов иностранных языков, Высшая школа, Москва.

Ширяев, А.Ф. (1979b), Синхронный перевод. Деятельность синхронного переводчика и методика преподавания синхронного перевода, Воениздат, Москва.

\section{Wykaz autoreferatów dysertacji}

\section{Nauki pedagogiczne}

Алексеева, В.В. (2006), Методика обучения переводу деловых писем с листа (китайский язык): автореф. дис. ... канд. пед. наук, Москва.

Аликина, Е.В. (2002), Обучение переводческой записи как программе порождения устного текста перевода: автореф. дис. ... канд. пед. наук, Екатеринбург.

Арутюнян, А.М. (2013), Методическая система обучения устному переводу в профессиональном курсе английского языка: автореф. дис. ... канд. пед. наук, Ереван.

Бакало, Д.И. (2003), Формирование готовности к переводу лингвокультурологических особенностей устного высказывания (языковой вуз): автореф. дис. ... канд. пед. наук, Томск.

Бассуэ, В.Л.К. (1991), Методика обучения переводу с листа как профессиональной деятельности (на материале английского и испанского языков): автореф. дис. ... канд. пед. наук, Москва.

Белькова, Е.В. (2009), Методика обучения абзацно-фразовому переводу студентов экономического вуза (дополнительная квалификация, английский язык): автореф. дис. ... канд. пед. наук, Иркутск.

Букарева, М.М. (1986), Интенсификация самостоятельной внеаудиторной учебной деятельности студентов с использованием ТСО при формировании профессиональных умений переводчика (английский язык): автореф. дис. ... канд. пед. наук, Москва. 
Гавриленко, Н.Н. (1989), Обучение аудированию как компоненту профессиональной деятельности переводчика: автореф. дис. ... канд. пед. наук, Москва.

Гоман, Ю.В. (2002), Методика обучения синхронной переводческой деятельности студентов старших курсов языковых вузов: автореф. дис. ... канд. пед. наук, Санкт-Петербург.

Готов, Г. (1999), Профессионально-ориентированное обучение устному переводу на старших курсах языкового вуза Монголии: автореф. дис. ... канд. пед. наук, Москва.

Григорьева, И.А. (1988), Методика обучения двустороннему переводу: автореф. дис. ... канд. пед. наук, Москва.

Емельянова, Я.Б. (2005), Совершенствование процесса обучения устному переводу с учетом формирования лингвострановедческой компетенции на 4-5 курсах переводческого факультета лингвистического вуза (экономическая тематика): автореф. дис. ... канд. пед. наук, Москва.

Железнякова, О.В. (2010), Обучение студентов языкового вуза устному последовательному переводу с использованием видеоматериалов (английский язык): автореф. дис. ... канд. пед. наук, Минск.

Живова, Ж.В. (1998), Методика обучения переводу с листа французских экономических текстов: автореф. дис. ... канд. пед. наук, Москва.

Идрисов, Ф.Ф. (1987), Обучение аудированию оригинальной английской разговорной речи при подготовке переводчика-референта (на продвинутом этапе): автореф. дис. ... канд. пед. наук, Москва.

Карпова, Ю.А. (2011), Формирование коммуникативных умений эмотивноэмпатийного взаимодействия будущего устного переводчика: автореф. дис. ... канд. пед. наук, Нижний Новгород.

Касаткина, К.А. (2000), Профессионально-ориентированное обучение переводу с листа текста делового письма на языковых факультетах вузов: автореф. дис. ... канд. пед. наук, Тольятти.

Князева, О.В. (2006), Модель сочетания традиционных и инновационных технологий в профессиональной подготовке лингвистов-переводчиков на примере курса устного перевода: автореф. дис. ... канд. пед. наук, Ставрополь.

Кондрашина, Т.В. (2012), Методика обучения образному монологическому высказыванию будущего переводчика: автореф. дис. ... канд. пед. наук, Екатеринбург. 
Корзун, О.О. (2008), Методика совершенствования темпа речи будущих переводчиков (английский язык): автореф. дис. ... канд. пед. наук, Москва.

Миньяр-Белоручев, Р.К. (1956), Методика обучения переводу на слух в курсе военного перевода (на материале французского языка): автореф. дис. ... канд. пед. наук, Москва.

Миньяр-Белоручев, Р.К. (1970), Методика обучения последовательному переводу: автореф. дис. ... др-а пед. наук, Москва.

Мишин, М.М. (1981), Использование учебного цветного телевидения в процессе профессиональной подготовки переводчиков (теоретикоэкспериментальное обоснование): автореф. дис. ... канд. пед. наук, Москва.

Панова, А.Н. (2014), Методика применения игрового моделирования с целью совершенствования профессиональной компетенции устного переводчика: автореф. дис. ... канд. пед. наук, Нижний Новгород.

Пушкина, А.В. (2015), Обучение устному последовательному переводу студентов-лингвистов в рамках программы „второе высшее образование": автореф. дис. ... канд. пед. наук, Москва.

Руцкая, Е.А. (2012), Формирование речевых информационнонаправленных навыков аудирования будущего устного переводчика: автореф. дис. ... канд. пед. наук, Нижний Новгород.

Самойленко, Г.А. (1998), Методика обучения устному переводу: первый этап: автореф. дис. ... канд. пед. наук, Москва.

Сафонова, И.И. (1991), Методика формирования устной переводческой компетенции в сфере профессионального общения (нефилологический вуз): автореф. дис. ... канд. пед. наук, Киев.

Тихонова, Е.В. (2014), Обучение будущих лингвистов устному последовательному переводу на основе анализа дискурса аудиои видеоматериалов (китайский язык; профиль „Перевод и переводоведение"): автореф. дис. ... канд. пед. наук, Томск.

Фадеев, И.А. (2001), Обучение конспективной системе записи (КОНСИ) при подготовке специалистов-переводчиков (на материале французского языка): автореф. дис. ... канд. пед. наук, Нижний Новгород.

Халеева, И.И. (1990), Основы теории обучения пониманию иноязычной речи (подготовка переводчиков): автореф. дис. ... др-а пед. наук, Москва. 
Цуциева, М.Г. (2006), Обучение военных врачей устному двустороннему переводу в ситуациях выполнения профессиональной деятельности (на материале немецкого языка): автореф. дис. ... канд. пед. наук, Санкт-Петербург.

Чуксина, О.В. (2000), Обучение профессионально-направленной переводческой деятельности в военном инженерном вузе (английский язык, курс по дополнительной специальности „Перевод в сфере профессиональной коммуникации"): автореф. дис. ... канд. пед. наук, Тамбов.

Швецова, Ю.О. (2012), Методика формирования системы экстралингвистических знаний студентов вуза при обучении устному переводу: автореф. дис. ... канд. пед. наук, Нижний Новгород.

Ярошенко, О.Н. (2007), Развитие перцептивно-коммуникативной компетентности будущих переводчиков: автореф. дис. ... канд. пед. наук, Екатеринбург.

\section{Nauki filologiczne (językoznawstwo)}

Андриянов, В.В. (1976), Психолингвистические аспекты устного перевода как вида речевой деятельности: автореф. дис. ... канд. филол. наук, Москва.

Гурин, И.В. (2009), Приемы речевой компрессии при синхронном переводе с русского языка на английский: автореф. дис. ... канд. филол. наук, Москва.

Жаркова, Г.Г. (1990), Психолингвистическая модель перевода с листа: автореф. дис. ... канд. филол. наук, Москва.

Зеленов, Ю.С. (1987), Психолингвистический анализ зависимости смысловой переработки текста от условий его предъявления (на материале устного перевода с иностранного языка на русский): автореф. дис. ... канд. филол. наук, Москва.

Илюхин, В.М. (2002), Стратегии в синхронном переводе (на материале англо-русских и русско-английской комбинаций перевода): автореф. дис. ... канд. филол. наук, Москва.

Макаренко, А.С. (2002), Стратегии решения проблем в последовательном переводе: автореф. дис. ... канд. филол. наук, Москва.

Сладковская, Е.Н. (1979), Анализ номинативного аспекта текста (на материале синхронного перевода с английского языка на русский): автореф. дис. ... канд. филол. наук, Москва. 
Чачибая, Н.Г. (1989), Особенности синхронного перевода дискуссии на естественно-научную тему с учетом ее структурно-семантических характеристик (на материале англо-русской и русско-английской комбинаций перевода): автореф. дис. ... канд. филол. наук, Москва.

Чернов, Г.В. (1980), Лингвистические основы синхронного перевода: автореф. дис. ... др-а филол. наук, Москва.

Ширяев, А.Ф. (1973), Синхронный перевод с французского языка (исследование некоторых аспектов синхронности в связи с особенностями функционирования исходного языка): автореф. дис. ... канд. филол. наук, Москва.

Ширяев, А.Ф. (1979а), Специализированная речевая деятельность (психолингвистическое исследование на материале синхронного перевода): автореф. дис. ... др-а филол. наук, Москва.

\section{Nauki psychologiczne}

Алексеева, Т.Д. (1992), Функциональное взаимодействие оперативной и долговременной памяти при овладении устным переводом: автореф. дис. ... канд. психол. наук, Минск.

Бенедиктов, Б.А. (1972), Общие и темпоральные особенности устного перевода и владения языками: автореф. дис. ... др-а психол. наук, Ленинград.

\section{Skróty}

автореф. дис. ... канд. пед. наук - автореферат диссертации на соискание ученой степени кандидата педагогических наук автореф. дис. ... канд. псих. наук - автореферат диссертации на соискание ученой степени кандидата психологических наук автореф. дис. ... канд. филол. наук-автореферат диссертации на соискание ученой степени кандидата филологических наук автореф. дис. ... др-а пед. наук - автореферат диссертации на соискание ученой степени доктора педагогических наук автореф. дис. ... др-а психол. наук - автореферат диссертации на соискание ученой степени доктора психологических наук автореф. дис. ... др-а филол. наук - автореферат диссертации на соискание ученой степени доктора филологических наук 
STRESZCZENIE

W artykule została podjęta próba chronologizacji, systematyzacji i oceny dorobku translatoryki rosyjskiej poświęconego różnym aspektom dydaktyki tłumaczenia ustnego, dokonana na materiale autoreferatów dysertacji przedstawionych do obrony w latach 1956-2015.

Słowa kluczowe: historia badań nad przekładem, dydaktyka przekładu, thumaczenie ustne, metodologia badań

SuMmary

Didactics of interpreting: from the history of Russian research

The author makes an attempt to organise chronologically, systematise and evaluate the Russian works devoted to various aspects of teaching oral translation, based on the material of annotations of dissertations submitted for defence in the years 1956-2015.

Key words: the history of translation studies, didactics of translation, interpreting, research methodology 